\title{
PERAN PEREMPUAN DALAM MENDUKUNG EKONOMI KELUARGA STUDI PADA KELUARGA NELAYAN DI DEWANTARA ACEH UTARA
}

\author{
Muhammad Zawil Kiram, ${ }^{1)}$ Zamzami ${ }^{2)}$ \\ ${ }^{1}$ Marmara University, Istanbul Turki, mzawil@ marun.edu.tr \\ ${ }^{2}$ Universitas Islam Negeri Ar Raniry, Banda Aceh
}

\begin{abstract}
This study aims to explore women's roles in supporting the economic needs of fishermen's families in Dewantara Aceh Utara, focusing on two questions. Firstly, what are the reasons for women to work and earn a living? Secondly, how women support the family's economy and in what sectors they work? This research was conducted through a qualitative method with primary data collection techniques including socio-economic surveys, participant observations, and interviews. Furthermore, the research data was compiled with a comprehensive secondary literature review that correlates with the research topic. The result of this study showed that the reasons for women to work and earn living are to increase family income, to reduce family burdens, to make friends/socialize, to uphold the belief that both men and women are responsible for working in the family, and play an active role in village/regional and national development. Most of the women from fishermen's families work in the brick-making sector, salt farming, wholesaler, cake making, and laundry. The contributions that women give to their families are to help fulfill their daily needs and also pay for school fees.
\end{abstract}

Keywords: Women, Role, Family Economy, Fishermen, North Aceh.

\begin{abstract}
ABSTRAK
Tujuan dari penelitian ini adalah untuk mengetahui peran perempuan dalam mendukung kebutuhan ekonomi keluarga nelayan di Dewantara Aceh Utara, dengan fokus kepada dua pertanyaan. Pertama, apa alasan perempuan untuk bekerja dan mencari nafkah? Kedua, bagaimana perempuan mendukung ekonomi keluarga dan di sektor apa saja mereka bekerja? Penelitian ini dilakukan melalui metode kualitatif dengan teknik pengumpulan data primer meliputi survei sosial ekonomi, observasi partisipan, dan wawancara. Sedangkan data penelitian sekunder dilengkapi dengan studi pustaka yang komprehensif dengan mempelajari buku-buku dan artikel yang memiliki keterkaitan dengan topik penelitian. Hasil penelitian ini menunjukkan bahwa alasan perempuan bekerja dan mencari nafkah adalah untuk meningkatkan pendapatan keluarga, mengurangi beban keluarga, untuk berteman/bersosialisasi, serta bekerja sebagai tanggung jawab laki-laki dan perempuan, dan berperan aktif dalam pembangunan desa/daerah/nasional. Sebagian besar perempuan dari keluarga nelayan bekerja di sektor pembuatan batu bata, petani garam, pedagang grosir, pembuat kue, dan tukang cuci. Kontribusi yang diberikan perempuan kepada keluarganya adalah dengan membantu memenuhi kebutuhan sehari-hari dan juga membayar biaya sekolah anak-anak.
\end{abstract}

Kata Kunci: Perempuan, Peran, Ekonomi Keluarga, Nelayan, Aceh Utara. 


\section{PENDAHULUAN}

Indonesia merupakan negara maritim dengan garis pantai yang begitu luas. Salah satu provinsi yang memiliki potensi laut yang luar biasa adalah provinsi Aceh. Luas daratan provinsi Aceh sebesar $57.365 .67 \mathrm{~km}^{2}$, sedangkan luas perairannya mencapai $295.370 \mathrm{~km}^{2}$ yang terdiri dari $56.563 \mathrm{~km}^{2}$ berupa perairan teritorial dan kepulaun serta $238,807 \mathrm{~km}^{2}$ berupa zona ekonomi esklusif (ZEE). Dengan panjang garis pantai mencapai $2.666 .3 \mathrm{~km}$, Aceh juga memiliki 199 pulau dengan posisi geoekonomi dan geopolitik yang sangat strategis. Dimana sebelah utara dan timur berbatasan langsung dengan selat Malaka, sebelah selatan dengan provinsi Sumatera Utara dan sebelah barat dengan Samudera Hindia (Mukhtar, 2017).

Luasnya daerah perairan dan garis pantai ini telah menjadikan sebagian besar masyarakat Aceh berprofesi sebagai nelayan dan petani garam. Namun, terlepas dari luasnya perairan dan sumber daya yang dimiliki oleh laut Aceh, kehidupan nelayan masih di bawah garis kemiskinan. Tidak hanya itu, per September 2019 terdapat 810.000 jiwa atau sebesar 15,01\% masyarakat Aceh hidup di bawah garis kemiskinan, menempatkan Aceh pada posisi pertama sebagai provinsi termiskin di Pulau Sumatera dan posisi keenam tingkat nasional (Kiram, 2020a).

Sebagian besar pendapatan yang diperoleh para nelayan masih belum stabil. Hal ini dikarenakan pemasukan para nelayan hanya bergantung kepada aktivitas penangkapan ikan sehingga berefek kepada ekonomi keluarga. Selain itu, musim penangkapan ikan biasanya pada musim kemarau, karena nelayan relatif tidak memiliki hambatan yang berarti saat melaut. Sedangkan musim paceklik biasanya terjadi saat musim hujan karena pada saat itu, gelombang tinggi dan hujan badai bisa terjadi setiap saat sehingga membuat para nelayan tidak bisa melaut untuk menangkap ikan.

Waktu yang dimanfaatkan untuk melaut dalam satu bulan hanya dua puluh hari, sementara sepuluh hari sisanya mereka relatif tidak melaut dan dengan demikian mereka juga tidak mendapatkan pemasukan. Salah satu contohnya adalah nelayan di Desa Geulumpang Sulu Timur Kabupaten Aceh Utara. Berdasarkan penjelasan dari Panglima Laot (pemuka adat laut) Aceh Utara menyebutkan bahwa penghasilan nelayan sangat minim dan masih di bawah Rp. 100.000 per hari, bahkan sebagian besar dari nelayan hanya bisa mendapatkan pemasukan sebesar Rp. 30.000 per hari.

Kondisi ekonomi yang tidak menentu ini menuntut para perempuan untuk berkontribusi dalam memenuhi kebutuhan ekonomi keluarga dengan ikut bekerja. Persepsi tentang perempuan sebagai istri yang mengurus rumah dan menjaga anak-anak kian hari semakin memudar akibat tuntutan ekonomi yang mengharuskan perempuan terjun ke ranah publik. Namun demikian, bukan 
berarti bahwa tugas domestik perempuan dinomor-duakan, melainkan perempuan di Desa Guelumpang Sulu Timur memainkan peran penting baik dalam melaksanakan kewajibannya dalam rumah tangga sekaligus menjadi penyedia kebutuhan ekonomi keluarga.

Ekonomi adalah salah satu konsep penting dalam keberlangsungan keluarga yang dapat didefiniskan sebagai semua kegiatan yang menghasilkan pendapatan (Iryani \& Mauliza, 2020). Ekonomi rumah tangga adalah kegiatan anggota keluarga yang menghasilkan pendapatan, tabungan atau menghasilkan barang-barang yang dapat digunakan oleh anggota keluarga. Jadi peran perempuan terhadap ekonomi keluarga dapat dikatakan sebagai semua kegiatan yang dilakukan oleh perempuan yang dapat menghasilkan pendapatan.

Dalam konteks ini, peran ekonomi perempuan di pedesaan Aceh biasanya sering ditemukan di bidang pertanian (ladang atau sawah), pekerjaan lainnya seperti mengajar, menjahit, berjualan dan aktivitas lainnya yang menghasilkan uang dan meringankan beban pengeluaran keluarga. Perempuan-perempuan di pedesaan pada dasarnya sangat berkontribusi dalam pemenuhan ekonomi keluarga yang disebabkan oleh tidak menetapnya pekerjaan suami, banyaknya kebutuhan yang harus dipenuhi, ataupun hal lainnya.

Kesulitan ekonomi yang dihadapi oleh rumah tangga nelayan pada umumnya membuat perempuan harus membantu mencari nafkah tambahan bagi keluarga. Oleh karena itu penelitian ini menekankan kepada peran perempuan dalam membantu memenuhi ekonomi keluarga pada keluarga nelayan desa Geulumpang Sulu Timur Kecamatan Dewantara Kabupaten Aceh Utara serta memfokuskan kepada motivasi yang mendasari mereka untuk bekerja, bagaimana peran yang dilakukan oleh perempuan dalam membantu ekonomi keluarga, dan bagaimana bentuk-bentuk pekerjaan yang mereka lakukan untuk menambah pendapatan keluarga.

\section{Keluarga dalam Pandangan Teori Struktural Fungsional}

Fungsionalis memandang unit keluarga sebagai institusi yang mempunyai fungsi penting dalam menjaga kelancaran masyarakat. Fungsionalis mengidentifikasi sejumlah fungsi yang harus dijalankan oleh keluarga meliputi fungsi reproduksi, sosialisasi, perawatan, perlindungan, dukungan emosional, penetapan status, dan regulasi perilaku seksual melalui penanaman norma sosial. Bagi fungsionalis, keluarga menciptakan anggota masyarakat yang terintegrasi baik dengan menanamkan sosial budaya pada anak-anak. Struktural fungsional memandang masyarakat sebagai sistem kompleks yang bagian-bagiannya bekerjasama untuk mendorong solidaritas dan stabilitas. Dengan cara ini, masyarakat seperti organisme dan setiap aspek masyarakat (lembaga, konstruksi 
sosial, dan sebagainya) seperti organ yang bekerja bersama untuk menjaga agar keseluruhan berfungsi dengan lancar.

Prinsip-prinsip pokok fungsionalisme adalah sebagai berikut: 1) Masyarakat adalah sistem yang kompleks terdiri dari bagian-bagian yang saling berhubungan dan saling tergantung, dan setiap bagian ini memiliki pengaruh besar atau saling mempengaruhi terhadap bagian-bagian lainnya. 2) Setiap bagian dalam masyarakat ada karena bagian tersebut memiliki peran penting dalam menjaga eksistensi dan stabilitas masyarakat secara keseluruhan. 3) Setiap masyarakat memiliki cara untuk terhubung, yaitu mekanisme yang dapat merekatkannya menjadi satu. Bagian penting dari proses ini adalah komitmen anggota masyarakat terhadap keyakinan dan nilai ideologis yang sama. 4) Masyarakat cenderung mengarah kepada suatu keadaan yang seimbang tanpa gangguan, jika terdapat gangguan pada salah satu bagiannya cenderung menimbulkan penyesuaian pada bagian lain agar tercapai harmoni dan stabilitas. 5) Perubahan sosial merupakan kejadian yang tidak biasa dalam masyarakat, tetapi bila itu terjadi, maka perubahan pada umumnya akan membawa kepada dampak-dampak yang menguntungkan masyarakat secara keseluruhan (Sanderson, 2000).

Sama halnya seperti masyarakat struktural fungsional melihat keluarga sebagai unit yang memiliki fungsi tertentu yang harus dijalankan agar terjadinya keluarga yang stabil dan harmonis. Jika terdapat salah satu organ atau anggota keluarga yang tidak mampu menjalankan fungsinya, maka yang lain akan mengambil alih untuk memperbaiki keadaan dan menjaga kestabilan istitusi keluarga tersebut. Berdasarkan teori struktural fungsional fenomena yang terjadi di masyarakat nelayan Desa Geulumpang Sulu Timur adalah terjadinya ganguan pada pemenuhan fungsi suami dalam menjamin keamanan ekonomi, sehingga anggota keluarga lainnya, dalam hal ini pihak istri harus mengambil tindakan untuk mengembalikan kestabilan dalam keluarga dengan ikut serta mencari pemasukan. Sehingga masalah yang ditimbulkan oleh kegagalan suami dalam memenuhi semua kebutuhan keluarga dapat tertutupi.

\section{METODE PENELITIAN}

Penelitian ini dilakukan di Desa Geulumpang Sulu Timur, Kecamatan Dewantara, Kabupaten Aceh Utara, Provinsi Aceh. Alasan peneliti mengambil tempat ini adalah karena setiap aktivitas para aktor dan fenomena yang hendak diteliti terdapat di daerah tersebut. Selain itu, di daerah inilah lokasi tempat tinggal para nelayan dan tempat mereka melaksanakan aktivitas seharihari sehingga peneliti dapat mengamati langsung aktivitas-aktivitas mereka. Metode yang peneliti gunakan dalam penelitian ini adalah metode kualitatif dengan hasil analisis berbentuk deskriptif 
yang bermaksud untuk memperoleh gambaran secara komprehensif dan lebih mendalam yang digambarkan dalam bentuk kata-kata.

Informan penelitian yang telah peneliti temukan di lapangan terdiri dari tiga kelompok, yaitu: 1) Informan Kunci, adalah aktor-aktor yang terlibat dalam permasalahan yang hendak diteliti terutama para nelayan yang ada di Desa Geulumpang Sulu Timur. 2) Informan Ahli, yaitu para ahli yang sangat memahami dan dapat memberikan penjelasan tentang berbagai hal yang berkaitan dengan penelitian dan tidak dibatasi dengan wilayah tempat tinggal. Dalam hal ini, yang peneliti temukan sebagai informan ahli adalah para aparatur Desa seperti Keuchik (Kepala Desa), Sekretaris Desa, dan aparatur desa lainnya. 3) Informan Insidental, yaitu siapa saja yang ditemukan di wilayah penelitian dan dianggap dapat memberikan informasi tentang masalah yang diteliti. Dalam hal ini, peneliti mengklasifikasikan informan insidental sebagai masyarakat Desa Geulumpang Sulu Timur yang sudah sering berinteraksi dengan nelayan-nelayan di desa tersebut.

Data primer dalam penelitian ini diperoleh dari hasil observasi, wawancara, dan data-data dokumentasi yang dimiliki oleh Desa Geulumpang Sulu Timur, kemudian data penelitian diperkuat oleh data sekunder yang diperoleh dengan kajian studi pustaka secara luas terhadap literatur yang tersedia baik berupa buku, artikel, jurnal, maupun publikasi lainnya yang terkait dengan topik penelitian.

\section{HASIL DAN PEMBAHASAN}

\section{Protret Goegrafis dan Demografis Desa Geulumpang Sulu Timur}

Desa Geulumpang Sulu Timur merupakan salah satu desa yang terletak di Kecamatan Dewantara Kabupaten Aceh Utara Provinsi Aceh. Terletak di pesisir pantai Selat Malaka menjadikan desa ini sebagai lokasi yang strategis untuk kegiatan nelayan. Kepada peneliti Kepala Desa mengatakan bahwa jumlah penduduk di Desa Geulumpang Sulu Timur mencapai 2.103 jiwa dengan jumlah kepala keluarga 450 orang yang tersebar di empat dusun (RW) meliputi Dusun Pasi Kuala, Dusun Meunasah, Dusun Bahrul Ulum, dan Dusun Geulumpang Jaya.

Adapun batas-batas wilayah desa Geulumpang Sulu Timur adalah berbatasan dengan Desa

Tupin di sebelah barat, berbatasan dengan Desa Bluka Teubai di sebelah Timur, Desa Ulee Releng di sebelah Selatan dan Laut Selat Malaka di sebelah Utara. Sistem pemerintahan Desa Geulumpang Sulu Timur dikepalai oleh seorang Keuchik (Kepala Desa) secara umum dan Kepala Dusun (Kadus) dalam ruang lingkup yang lebih kecil. Setiap Kepala Dusun berada di bawah pimpinan Keuchik dan diberikan tanggung jawab untuk mengatur dusun (RW) dengan tujuan pengelolaan desa dapat berjalan dengan baik. 
Tidak hanya letak geografisnya yang menarik perhatian, memasuki desa yang dipimpin oleh Keuchik Adnan ini pengunjung juga betah berlama-lama dengan keramahan dan relijiuitas masyarakatnya. Anak-anak kecil yang riang bermain air dan pasir di tepi pantai, aktivitas nelayan memperbaiki perahu mereka, memperbaiki jaring, dan tidak jarang pula pemandangan tareek pukat menjadikan suasana batin siapa saja yang bertamu merasa senang dengan keadaan desa ini. Dilihat dari segi aspek sosial budaya, masyarakat Desa Geulumpang Sulu Timur memiliki kesamaan dengan desa tetangganya Bluka Teubai dimana keduanya memiliki keadaan sosial budaya yang unik, di Geulumpang Sulu Timur masih terdapat sistem solidaritas mekanik yang ditanamkan oleh masyarakat setempat.

Hal ini dapat kita lihat dalam kehidupan dan aktivitas-aktivitas sehari-hari mereka, baik dalam hal perekonomian, dan aspek lainnya. Solidaritas mekanik ini masih melekat erat dalam masyarakat Geulumpang Sulu Timur sehingga membuat tali persaudaraan antara mereka sangat kuat. Mereka masih menerapkan tolong menolong dan juga gotong royong. Misalkan dalam aktivitas jak u laot (melaut), masyarakat Gelumpang Sulu Timur masih menerapkan tolong menolong di mana dalam proses melaut ini, masyarakat bekerjasama dengan pemilik bot atau pun membantu nelayan yang hendak melaut atau nelayan yang pulang. Aktivitas ini dikenal dengan nama tareek bot (membantu nelayan yang pulang dari menangkap ikan).

Kerjasama yang dilakukan pada aktivitas tareek bot ini juga membawa keuntungan kepada semuanya, di mana nelayan yang baru saja pulang menangkap ikan memberikan sebagian ikan mereka kepada masyarakat yang telah membantu sang nelayan. Aktivitas ini pada dasarnya juga membantu masyarakat di pinggir pantai, karena ketika mereka membantu sang nelayan mereka juga bisa mendapatkan ikan tanpa harus membeli, dengan demikian akan menghemat pengeluaran mereka (Kiram, 2020b).

\section{Profil Masyarakat Nelayan Desa Geulumpang Sulu Timur}

Sebelum tahun 2018, para nelayan di desa Geulumpang Sulu Timur berdomisili secara terpisah di dusun bahkan desa yang berbeda. Akan tetapi setelah pemerintah memberikan bantuan rumah kepada masyarakat nelayan yang ada di Kecamatan Dewantara (tidak terkecuali kepada nelayan di Desa Geulumpang Sulu Timur), menjelang akhir tahun 2018 para nelayan di Desa Geulumpang Sulu Timur menetap di perumahan nelayan yang dibangun di pesisir pantai Desa Geulumpang Sulu Timur tepatnya di Dusun Pasi Kuala.

Bantuan rumah bagi nelayan ini merupakan program dari Kementerian Kelautan dan Perikanan Republik Indonesia pada tahun 2018 dengan membangun 50 unit rumah tipe 36 plus di 
Gampong Gelumpang Sulu Timur. Pemerintah juga membantu perabotan rumah tangga, seperti ranjang beserta kasur, sofa, hingga lemari. Saat ini terdapat sebanyak 40 keluarga yang tinggal di perumahan ini yang termasuk dalam kategori nelayan. Sedangkan 10 keluarga yang lain adalah masyarakat yang mendapatkan rumah sebagai ganti rugi atas tanah yang mereka berikan sebagai lahan perumahan (tidak dianggap sebagai nelayan). Total jumlah anggota keluarga nelayan adalah 143 orang. 40 diantara mereka adalah kepala keluarga (dengan penghasilan rata-rata Rp. 100.000 per hari), 40 orang perempuan ibu rumah tangga, dan sebanyak 63 orang anak-anak dengan rentang usia 4 sampai 17 tahun (usia sekolah).

Dari segi sosial, ekonomi, dan pendidikan masyarakat nelayan di Geulumpang Sulu Timur masih bisa dikatakan belum mampuni. Hal ini dibuktikan dengan hasil survey yang peneliti lakukan terkait jenjang pendidikan dan pendapatan keluarga para nelayan. Peneliti menemukan bahwa dalam komunitas masyarakat nelayan di Desa Geulumpang Sulu Timur hanya 4 orang dari mereka yang menempuh pendidikan sampai D4/Sarjana, sedangkan mayoritas lainnya hanya menamatkan Sekolah Dasar dan Sekolah Menengah Pertama.

Sedangkan dari segi kondisi ekonomi, kehidupan nelayan di desa Geulumpang Sulu Timur masih memprihatinkan dan penghasilannya hanya bisa dan kadang kala masih kurang untuk memenuhi kebutuhan sehari-hari karena sebagian besar nelayan di desa tersebut hanya mengandalkan hasil tangkapan untuk menopang kehidupannya, padahal dalam melaut sangat mengandalkan cuaca yang tidak menentu. Pada umumnya nelayan ini berlayar menggunakan perahu mesin (bot) yang berukuran kecil dan ada juga yang menggunakan perahu besar (kapal). Bahkan sebagian nelayan ada yang hanya menggunakan bot milik Tokee (bos/atasan) dengan sistem bagi hasil dan tidak memiliki bot sendiri.

Dari usaha dan kerja keras yang mereka lakukan, pendapatan para nelayan hanya sekedar untuk memenuhi kebutuhan sehari-hari mereka, hal ini ditunjukkan dengan masih rendahnya standar hidup di kalangan masyarakat pesisir ini termasuk dalam segi pemenuhuan alat-alat rumah tangga seperti mesin cuci dan pendidikan anak (sebanyak 5 diantara anak-anak di desa ini hanya menamatkan sekolah menengah atas dan tidak menlanjutkan ke universitas). Selain itu masyarakat nelayan di desa ini masih memiliki tingkat ketergantungan terhadap pinjaman dan utang yang tinggi. Penghasilan bersih yang didapatkan oleh nelayan hanya berkisar Rp. 100.000 per hari sehingga keadaan ekonomi yang tidak stabil membuat perempuan-perempuan di desa ini harus bekerja untuk mendukung ekonomi keluarga. 


\section{Motivasi Perempuan Keluarga Nelayan Desa Geulumpang Sulu Timur untuk Bekerja}

Di provinsi Aceh, perempuan dan laki-laki memiliki peran yang berbeda dalam masyarakat. Perbedaan biologi antara perempuan dan laki-laki mengakibatkan adanya perbedaan dalam aktivitas sosial. Secara tradisional para perempuan berpartisipasi dalam ekonomi rumah tangga dengan melakukan kegiatan-kegiatan di dalam rumah seperti mengurus rumah, menjaga anakanak, dan hal-hal lainnya yang berkaitan dengan kegiatan domestik. Sedangkan laki-laki berperan sebagai penyedia ekonomi keluarga dan bekerja di luar rumah untuk memenuhi kebutuhan rumah tangga.

Akan tetapi dengan adanya krisis ekonomi yang terjadi dalam masyarakat, sekarang perempuan dan laki-laki terlibat dalam menghasilkan pendapatan untuk memenuhi kebutuhan pokok mereka. Sekarang banyak perempuan yang berpartisipasi secara aktif dalam mendukung ekonomi keluarga. Peran aktif perempuan ini tidak hanya disebabkan oleh adanya gerakan kesetaraan gender yang menyuarakan bahwa perempuan juga bisa berkecimpung di ruang publik melainkan adanya faktor lainnya yang memotivasi perempuan untuk bekerja, salah satunya adalah faktor ekonomi. Motivasi merupakan dorongan dalam diri seseorang untuk melakukan sesuatu atau mencapai satu tujuan tertentu. Motivasi ini berbeda-beda yang bisa dipengaruhi oleh motif, tujuan, kebutuhan hidup seseorang, juga waktu dan tempat.

Untuk mengetahui motif dan tujuan perempuan keluarga nelayan yang bekerja di Desa Geulumpang Sulu Timur peneliti melakukan wawancara dengan 34 orang perempuan di desa tersebut. Salah satunya adalah Ibu Nuraini yang berkerja di pabrik pembuatan batu bata. Beliau mengungkapkan sebagai berikut:

"Saya memiliki dua orang anak dan dua-duanya masih sekolah, yang satu di Sekolah Menengah Pertama dan satunya lagi masih di Sekolah Dasar. Kalau kami bergantung sama penghasilan suami kadang tidak cukup, karena kegiatan melaut tidak selalu rutin dan hasil tangkapanpun tidak terlalu banyak. Dalam sehari paling bisa dapat uang Rp. 300.000. Kalau kita potong untuk biaya modal seperti bahan bakar bot dan lain-lain sisanya hanya Rp. 100.000 atau Rp. 150.000. Tentu jumlah ini tidak akan cukup untuk memenuhi kebutuhan sehari-hari. Belum lagi kalau kadang dalam seminggu hanya bisa melaut 3 atau 4 hari, maka pendapatan suami tidak akan cukup. Makanya kami juga ikut bantu-bantu karena kegiatan lain juga tidak ada. Disini juga dekat dengan rumah, jadi sangat mudah keluar rumah langsung ke tempat kerja. Kalau tidak maka kami harus ngutang karena biaya tidak cukup." (Nuraini, Geulumpang Sulu Timur, 17/8/2020).

Motivasi utama yang mendorong perempuan di Desa Gelumpang Sulu Timur untuk bekerja adalah untuk menambah penghasilan keluarga karena pendapatan suami yang tidak mencukupi untuk memenuhi kebutuhan pokok dan besarnya biaya tanggungan keluarga. Adanya kerja 
tambahan yang dilakukan oleh perempuan dapat membantu pemasukan dan meringankan beban ekonomi keluarga. Peneliti menemukan bahwa tidak ada rasa keterpaksaan dalam diri perempuan keluarga nelayan untuk bekerja. Seperti yang dijabarkan oleh Ibu Nuraini diatas bahwa kegiatan yang dilakukannya juga untuk mengisi waktu kosong karena tidak memiliki kegiatan lain. Hal senada juga disampaikan oleh Bapak Syambudiman dan Ibu Mutiawati yang merupakan pemilik salah satu tempat pembuatan batu bata di Dusun Pasi Kuala.

"Memang para nelayan ini tidak memiliki pekerjaan lain selain melaut, oleh karena itu keadaan ekonomi juga rendah, bisa dikatakan kurang mampu. Kebetulan ketika perumahan nelayan ini dibangun kami juga sedang membuat tempat pembuatan batu-bata dan tidak lama kemudian para nelayan pun menetap di perumahan tersebut. Setelah beberapa minggu, ada beberapa orang yang minta kerja untuk buat batu bata di tempat kami, saat itu kami juga tidak memiliki orang yang bekerja. Jadi mereka langsung bekerja di sini." (Mutia, Geulumpang Sulu Timur, 6/9/2020).

"Keadaan mereka juga sama seperti kami sebetulnya, sama-sama susah, jadi dengan adanya mereka bekerja di sini kami juga bisa terbantu, mereka juga bisa menambah pemasukan sehari-hari dan setidaknya bisa membantu untuk uang makan. Karena selain melaut tidak ada pemasukan lain.” (Syambudiman, Geulumpang sulu Timur, 6/9/2020).

Dari ini dapat kita simpulkan bahwa motivasi utama perempuan di keluarga nelayan untuk bekerja adalah membantu meringankan ekonomi keluarga dan mencukupi kebutuhan keluarga sehingga mendorong mereka untuk produktif dan menggunakan waktu luang dengan mencari pendapatan tambahan. Di saat bersamaan perempuan di desa ini juga masih melaksanakan pekerjaan di rumah seperti mengurus anak-anak, mengurus rumah, melayani suami, dan kegiatan domestik lainnya. Untuk mendapatkan gambaran yang luas dan mendalam mengenai motivasi perempuan keluarga nelayan untuk bekerja, peneliti telah menyediakan beberapa alternatif alasan untuk ditentukan oleh para partisipan penelitian sebagaimana dijelaskan pada Tabel 1 di bawah ini.

Tabel 1. Alasan-Alasan Perempuan Keluarga Nelayan Bekerja

\begin{tabular}{|c|l|l|}
\hline No & \multicolumn{1}{|c|}{ Uraian } & \multicolumn{1}{|c|}{ Persentase } \\
\hline 1. & Alasan ekonomi & 34 \\
& $\begin{array}{c}\text { 1.1 Menambah penghasilan keluarga } \\
\text { 1.2 Meringankan beban keluarga }\end{array}$ & 30 \\
\hline 2. & $\begin{array}{l}\text { Alasan sosial } \\
\text { 2.1 Mencari teman/ bersosialisasi } \\
\text { 2.2 Menambah pengalaman }\end{array}$ & 6 \\
\hline 3. & $\begin{array}{l}\text { Alasan keterlibatan dalam pembangunan daerah/nasional } \\
\text { 3.1 Bekerja sebagai tanggung jawab laki-laki dan perempuan }\end{array}$ & - \\
\hline & 3.2 Berperan aktif dalam pembangunan desa/daerah/nasional & 15 \\
\hline
\end{tabular}

Sumber: Data Penelitian, 2020.

74 | Jurnal Ilmu Sosial dan Ilmu Politik Malikussaleh (JSPM) Volume 2 Nomor 1 Tahun 2021 
Berdasarkan Tabel 1 di atas, dari kategori alasan ekonomi dapat diketahui bahwa alasan untuk meningkatkan perekonomian keluarga dan menambah penghasilan keluarga adalah alasan yang paling banyak dipilih oleh partisipan penelitian mencapai 34 orang. Selain itu alasan untuk meringankan beban keluarga menjadi alasan kedua yang mendorong perempuan-perempuan di desa ini untuk berkecimpung dalam dunia perkerjaan. Jumlah partisipan yang memilih alasan ini mencapai 30 peserta. Data ini menunjukkan bahwa ikut bekerjanya istri di berbagai sektor bertujuan untuk membantu suami dalam mencukupi kebutuhan sehari-hari, baik kebutuhan pangan sampai pada kebutuhan biaya sekolah anak-anak.

Dalam kategori alasan sosial hanya enam peserta yang memilih alasan tersebut dengan tujuan mencari teman atau bersosialisasi dengan masyarakat sekitar. Sementara itu, seluruh partisipan menunjukkan bahwa mereka tidak memiliki motif untuk menambah pengalaman dengan

ikut bekerja dan membantu suami. Pada kategori keterlibatan dalam pembangunan nasional, 15 perempuan memilih bahwa perempuan dan laki-laki memiliki hak yang sama untuk berkerja dan membantu pemenuhan ekonomi keluarga sehingga perempuan juga mempunyai kesempatan yang sama untuk bekerja. Sedangkan untuk kategori pembangunan nasional, hanya 5 partisipan yang menjadikan alasan ini sebagai faktor pendorong bagi mereka untuk bekerja. Hal ini menunjukkan bahwa pemahaman masyarakat desa tentang partisipasi perempuan dalam pembangunan nasional masih rendah. Padahal ketika para perempuan ikut bekerja, maka kesejahteraan keluarga akan tercapai dan secara tidak langsung juga akan berpengaruh kepada kesejahteraan masyarakat setempat.

\section{Peran Perempuan Keluarga Nelayan dalam Membantu Ekonomi Keluarga}

Dalam penelitian yang dilakukan oleh Laila dan Amanah pada masyarakat nelayan di Dusun Sendang Biru, Desa Tambakrejo Malang Jawa Timur, menunjukkan bahwa sebanyak 12 responden memberikan kontribusi pemasukan sebesar 50\% dari total pendapatan rumah tangga. Data ini menunjukkan bahwa setengah dari kebutuhan keluarga dipenuhi oleh kaum perempuan (Nur Laila \& Amanah, 2016). Keterlibatan istri dalam mencari pemasukan pada masyarakat pesisir merupakan sebuah pola adaptasi dalam kehidupan yang umumnya dilakukan oleh kebanyakan masyarakat pesisir di berbagai tempat di Indonesia, termasuk di Desa Geulumpang Sulu Timur.

Status perempuan sebagai ibu rumah tangga yang bertugas menjaga rumah dan mengurus anak-anak tidak lagi berlaku dalam masyarakat Desa Geulumpang Sulu Timur. Pasalnya perempuan juga dituntut oleh keadaan ekonomi untuk bergerak dan mengepakkan sayap mereka ke ranah publik sekaligus menjadi penyedia kebutuhan keluarga. Aswiyati, (2016) dalam 
penelitiannya mengatakan bahwa perempuan di pedesaan bekerja bukan hanya untuk mengisi waktu luang, melainkan untuk mencari nafkah karena pendapatan suami kurang mencukupi dalam memenuhi kebutuhan keluarga. Hal ini sejalan dengan fenomena yang terjadi pada perempuan nelayan di Desa Geulumpang Sulu Timur yang bekerja untuk mencari nafkah dan tidak hanya sekedar mengisi waktu luang.

Peranan dan kedudukan perempuan dibagi dua yaitu peran dan kedudukannya di dalam keluarga sebagai tenaga kerja domestik yang berhubungan dengan pekerjaan-pekerjaan mengurus rumah tangga dan peran perempuan di luar keluarga termasuk usaha untuk mencari nafkah dan memperoleh penghasilan guna membantu ekonomi serta jangkauan sosial di luar rumah tangga (Ihromi, 1995). Hasil penelitian menunjukkan bahwa dalam keluarga nelayan di Desa Gelumpang Sulu Timur sebanyak 34 dari 40 perempuan ikut berpartisipasi dalam mendukung perekonomian keluarga dengan bekerja sebagai pembuat batu bata, petani garam, jualan grosir, menjahit, membuat kue, dan sebagai tukang cuci pakaian. Jumlah perempuan dari keluarga nelayan yang bekerja dapat dilihat pada tabel berikut.

Tabel 2. Jumlah Perempuan Keluarga Nelayan yang Bekerja Berdasarkan Jenis Pekerjaan

\begin{tabular}{|c|c|c|}
\hline No & Jenis Pekerjaan & Jumlah \\
\hline 1. & Membuat Batu Bata & 18 \\
\hline 2. & Petani Garam & 5 \\
\hline 3. & Jualan Grosir & 5 \\
\hline 4. & Menjahit & 2 \\
\hline 5. & Membuat Kue & 1 \\
\hline 6. & Tukang Cuci & 1 \\
\hline \multicolumn{2}{|r|}{ Total } & 34 \\
\hline
\end{tabular}

Sumber: Data Survey Penelitian, 2020.

Membuat batu bata merupakan pekerjaan yang paling banyak digeluti oleh perempuan keluarga nelayan di Desa Geulumpang Sulu Timur. Dari 34 perempuan terdapat 18 orang yang mengandalkan pendapatan dari hasil pembuatan batu bata. Proses pembuatan batu bata di semua pabrik yang ada di desa ini masih dilakukan secara tradisional (manual) tanpa menggunakan mesin. Koh batee adalah sebutan untuk proses pembuatan batu bata sedangkan untuk pabrik atau tempat pembuatan batu bata sendiri oleh masyarakat pesisir pantai Geulumpang Sulu Timur disebut Sal Bata. Proses pembuatan batu bata ini tergolong mudah namun membutuhkan waktu yang lama dan ketekunan.

Setelah melakukan observasi dan wawancara peneliti menemukan bahwa sebanyak 13 perempuan yang bekerja sebagai pembuat batu bata memiliki anak yang masih sekolah mulai dari 
jenjang TK, SD, SMP sampai SMA. Peneliti menemukan bahwa mendukung dan memenuhi pendidikan anak-anak juga merupakan salah satu faktor yang membuat perempuan nelayan di desa ini berusaha untuk mendapatkan penghasilan, seperti yang disampaikan oleh salah satu responden kepada peneliti sebagai berikut:

"Jadi nelayan itu penghasilannya tidak tetap, karena kadang melaut kadang tidak tergantung cuaca. Kalau saya tidak ikut mencari nafkah, keluarga kami kadang tidak bisa memenuhi kebutuhan pokok, makanya saya juga ikut bantu suami dengan menjadi buruh buat batu bata. Penghasilan saya tidak terlalu besar hanya Rp. 55.000 per seribu batu bata yang saya cetak. Kalau saya sehat dan tidak ada halangan apa-apa dalam seminggu bisa mencetak dua ribu sampai tiga ribu batu bata. Meskipun tidak banyak alhamdulillah cukup untuk makan sehari-hari dan juga untuk jajan anak sekolah.” (RT, Geulumpang Sulu Timur, 4/9/2020).

Berdasarkan hasil wawancara di atas dapat disimpulkan bahwa penghasilan yang didapatkan oleh perempuan yang bekerja sebagai pembuat batu bata adalah berdasarkan kuantitas batu bata yang mereka hasilkan. Dimana per seribu batu bata mereka mendapatkan Rp. 55.000 dengan lama waktu kerja dua sampai tiga hari tergantung kecepatan masing-masing pekerja. Secara kasar penghasilan perempuan pembuat batu bata dalam sebulan dapat mencapai mulai dari Rp. 440.000 sampai Rp. 660.000. Pendapatan yang mereka peroleh secara langsung telah membantu mereka dalam memenuhi kebutuhan sehari-hari dan juga dapat membantu biaya sekolah anakanak. Meskipun demikian pemasukan yang mereka terima masih jauh dari mencukupi mengingat pengeluaran setiap bulan melebihi pemasukan yang mereka dapatkan.

Perkerjaan lain yang digeluti oleh perempuan keluarga nelayan di desa ini adalah sebagai petani garam. Letak desa yang langsung berpapasan dengan pesisir laut menjadikan desa ini sebagai tempat yang ideal untuk bertani garam. Petani garam di Geulumpang Sulu Timur memproduksi garam secara tradisional dengan proses perebusan. Meskipun demikian terdapat halhal unik dalam proses pembuatan garam ini. Metode yang digunakan oleh petani garam di sini berbeda dengan masyarakat umumnya yang ada di Aceh maupun Indonesia yang langsung merebus air laut. Adapun tahapan pembuatan garam yang dilakukan oleh masyarakat Geulumpang Sulu Timur yaitu hu anoe (menggarap tanah), tireeh te (menyaring air), prom le (menyimpan air), dan taguen sira (perebusan).

Hu anoe (menggarap tanah) adalah proses pertama yang dilakukan dengan penggarapan tanah kering di pinggir laut atau tambak. Tireeh ie (menyaring air) adalah proses penyaringan air dengan mengumpulkan butiran-butiran tanah yang telah kering, dan dimasukkan ke dalam (panteu) tempat penyaringan air, kemudian disiram dengan air laut atau air tambak. Prom ie (penyimpanan air) merupakan proses setelah penyaringan air. Penyimpanan air dilakukan untuk mendapatkan 
kualitas air yang jernih dan mengandung banyak zat garam, sehingga menghasilkan garam yang banyak setelah proses perebusan. Taguen sira (perebusan) adalah proses terakhir yang dilakukan oleh petani garam Desa Geulumpang Sulu Timur. Perebusan ini dilakukan selama kurang lebih 10 jam untuk menghasilkan garam kristal (garam utuh).

Proses pembuatan garam membutuhkan waktu yang lama dan juga kesabaran yang besar selama proses perebusan. Kepada peneliti, AN salah satu partisipan mengatakan bahwa proses perebusan air hingga menjadi garam bisa sekitar 8 sampai 10 jam. Biasanya mereka mulai merebus dari jam 7 pagi hingga jam 5 sore untuk mendapatkan garam yang bagus dan siap untuk dijual. AN lebih lanjut memberikan penjelasan sebagai berikut:

"Prosesnya lumayan lama dan juga melelahkan, tapi kalau tidak dilakukan pekerjaan lain juga tidak ada. Setidaknya bisa mendapatkan pemasukan dari membuat garam ini. Biasanya saya merebusnya mulai pagi, jam tujuh atau delapan pagi sampai sore. Kemudian setelah garamnya terbentuk akan saya angkat dan tunggu sampai kering dan dingin, esokan harinya baru bisa saya jual. Harga untuk per kilogram sekarang cuma Rp. 5.000 dan sekali rebus kadang saya mendapatkan sekitar $15 \mathrm{~kg}$ sampai $20 \mathrm{~kg}$. Memang tidak banyak tapi bisa untuk menutupi kebutuhan sehari-hari, untuk beli beras dan sayur. Terutama kalau saat suami sedang tidak melaut.” (AN, Geulumpang Sulu Timur, 2/9/2020).

Berdasarkan wawancara peneliti dengan partisipan di atas dapat kita ketahui bahwa dengan proses pembuatan yang memakan waktu begitu lama penghasilan yang didapatkan oleh petani garam tidak terlalu besar. Secara kasar setiap harinya petani garam di Geulumpang Sulu Timur memperoleh pendapatan sebesar Rp. 50.000 hingga Rp. 100.000 dari hasil penjualan garam. Dengan adanya pemasukan tambahan dari pihak perempuan maka pemenuhan kebutuhan keluarga juga dapat terlaksana dengan baik.

Selain dua pekerjaan di atas beberapa perempuan keluarga nelayan di Geulumpang Sulu Timur juga berusaha mendapatkan pemasukan dengan berjualan grosir kebutuhan sehari-hari seperti beras, minyak, sayur-sayuran, dan makanan ringan untuk anak-anak setempat. Dari hasil survey dan wawancara peneliti menemukan bahwa penghasilan dari hasil jualan yang mereka dapatkan berkisar antara Rp. 50.000 sampai Rp. 100.000 per harinya. Pendapatan ini adakalanya digunakan untuk memenuhi kebutuhan sehari-hari dan juga untuk membeli barang dagangan selanjutnya. Dengan berjualan kecil-kecilan seperti ini perempuan nelayan mengaku bahwa mereka bisa membantu meringankan beban ekonomi keluarga dibandingkan tanpa pemasukan sama sekali.

Kegiatan lainnya yang digeluti oleh perempuan nelayan adalah menyediakan jasa jahit pakaian, membuat kue, dan menjadi tukang cuci pakaian. AH kepada peneliti menjelaskan bahwa penghasilan yang didapatkannya dari menjahit pakaian sangat relatif tergantung banyaknya jumlah 
pesanan yang ia terima. Terkadang ia tidak menerima pesanan sama sekali selama bermingguminggu. Biaya yang diambil juga berdasarkan jenis jahitan yang diminta oleh konsumen. Biaya yang ia tetapkan untuk menjahit pakaian utuh adalah Rp. 120.000 dengan bahan dasar dari konsumen dan Rp. 300.000 jika bahan yang digunakan disediakan olehnya.

Pekerjaan yang dilakukan oleh AM sebagai pembuat kue juga tidak menentu tergantung jumlah kue yang dapat terjual per harinya. AM berjualan kue dengan menitipkannya di warungwarung kopi di Desa Gelumpang Sulu Timur. Penghasilan yang ia dapatkan per harinya berkisar antara Rp. 30.000 sampai Rp. 50.000. AM mengaku bahwa pendapatannya dapat digunakan untuk jajan anak sekolah dan membeli kebutuhan sehari-hari ketika suaminya sedang tidak bekerja.

Hal yang sama juga dilakukan oleh TH untuk meringankan beban ekonomi keluarga dengan menjadi tukang cuci. Dalam wawancara dengan peneliti TH menjelaskan bahwa pendapatannya sangat tergantung kepada jumlah pakaian yang ia cuci. Masyarakat Geulumpang Sulu Timur masih tergolong dalam penduduk dengan perekonomian menengah ke bawah sehingga kebanyakan orang memilih untuk mencuci pakaian mereka sendiri dibandingkan mencuci di laundry atau tempat cuci pakaian untuk menghemat biaya. Hal ini membuat TH hanya mendapatkan pesanan dengan jumlah yang sedikit. Dari setiap konsumen pendapatan per bulan yang ia dapatkan adalah Rp. 120.000. Ketika wawancara dilakukan TH mengatakan bahwa ia memiliki enam konsumen tetap sehingga per bulan pendapatan kasar yang ia terima mencapai Rp. 720.000. Pendapatan ini cukup untuk memenuhi kebutuhan keluarga ketika suaminya sedang tidak melaut dan tidak mendapatkan pemasukan sama sekali.

Secara keseluruhan dapat kita simpulkan bahwa peran perempuan keluarga nelayan dalam memenuhi kebutuhan ekonomi keluarga adalah dengan membantu kebutuhan pokok sehari-hari dan juga menyediakan biaya sekolah (termasuk uang jajan) anak-anak. Meskipun usaha dan pekerjaan yang mereka lakukan adalah di sektor yang kecil, akan tetapi dampak yang mereka berikan kepada keluarga sangat bisa dirasakan oleh seluruh anggota rumah tangga. Hal ini menunjukkan bahwa aksi yang diambil oleh perempuan untuk menutupi kegagalan suami dalam menjalankan fungsinya dalam keluarga dapat mengembalikan stabilitas ekonomi rumah tangga.

\section{KESIMPULAN}

Meskipun perairan provinsi Aceh meyediakan sumber daya alam yang besar, namun kehidupan para nelayan yang bergantung nasib kepada hasil tangkapan masih memprihatinkan. Adanya keadaan dimana kesulitan ekonomi menyelimuti keluarga nelayan membuat para perempuan bergerak untuk ikut serta dalam bekerja dan meringankan beban tersebut. Diantara 
motivasi yang medorong perempuan keluarga nelayan untuk bekerja dan mendapatkan penghasilan adalah untuk meringankan beban ekonomi, memenuhi kebutuhan keluarga, sebagai sarana untuk bersosialisasi dengan masyarakat, dan adanya pemahaman bahwa bekerja merupakan hak baik lakilaki maupun perempuan, serta juga untuk berpasrtisipasi dalam pembangunan desa, regional, dan nasional. Untuk membantu perekonomian keluarga perempuan nelayan di Geulumpang Sulu Timur bekerja di beberapa sektor yang berbeda seperti menjadi buruh membuat batu bata, petani garam, jualan grosir, membuat kue, mejahit pakaian, dan juga menjadi tukang cuci. Kontribusi yang diberikan oleh perempuan terhadap keluarga sangat bervariasi tergantung kepada pekerjaan yang mereka lakukan dan besarnya pendapatan yang mereka terima. Secara keseluruhan perempuan nelayan mampu memberikan kontribusi kepada keluarga dengan memenuhi kebutuhan sehari-hari seperti membeli beras dan lauk pauk serta membiayai sekolah anak-anak.

\section{DAFTAR PUSTAKA}

Aswiyati, I. (2016). Peran Wanita dalam Menunjang Perekonomian Rumah Tangga Keluarga Petani Tradisional untuk Penanggulangan Kemiskinan di Desa Kuwil Kecamatan Kalawat. Jurnal Holistik, Journal of Social and Culture IX(17).

Ihromi, T.O. (1995). Kajian Perempuan dalam Pembangunan. Yayasan Obor Indonesia.

Iryani, L., \& Mauliza, R. (2020). Sistem Pengelolaan BUMDes dalam Pembangunan Tambak Milik Desa Lhok Euncien Kecamatan Baktiya Barat Kabupaten Aceh Utara. Jurnal Ilmu Sosial dan Ilmu Politik Malikussaleh (JSPM), 1(2), 207-223.

Kiram, M. Z. (2020a). Good Governance, Key Factor for Social and Economic Development in Aceh: A Case Study in Aceh Province Indonesia. 6th UDEF International Symposium.

Kiram, M. Z. (2020b). Involusi Kesejahteraan Petani Garam (1st ed.). Tunas Bangsa Publisher.

Mukhtar, R. (2017). Masa Depan Aceh ke Laut Saja. Serambi Indonesia. www.serambi indonesia.com

Nur Laila, N. E., \& Amanah, S. (2015). Strategi Nafkah Perempuan Nelayan terhadap Pendapatan Keluarga. Sodality: Jurnal Sosiologi Pedesaan, 3(2), 159-168.

Sanderson, S. K. (2000). Macro Sociology. PT. RajaGrafindo Persada. 